Analysis 71 (2011): $68_{4}-687$. (please cite published version)

\title{
Two More for the Knowledge Account of Assertion
}

\author{
Matthew A. Benton
}

The Knowledge Account of Assertion (KAA) has received added support recently from data on prompting assertion (Turri 2010) and from a refinement suggesting that assertions ought to express knowledge (Turri 2011). This article adds another argument from parenthetical positioning, and then argues that KAA's unified explanation of some of the earliest data adduced in its favour recommends KAA over its rivals.

\section{An argument from parenthetical position}

Slote (1979) considers how we ought to assert a reasonable belief when one takes oneself not to know; for if, as KAA has it, flat-out asserting $p$ represents one as knowing that $p$, one should refrain from flat-out asserting when one takes oneself not to know. 'I believe that $p$ ' looks like the obvious candidate. But Slote is careful to distinguish between the form

(1) I believe that it's raining,

which could also be used merely for ascribing belief to oneself rather than expressing it, and a form which he thinks unambiguously serves to express a belief: the parenthetical constructions

(2) It is, I believe, raining

(3) It is raining, I believe,

where the doxastic hedge 'I believe' is parenthetically slotted at the middle or the end, seem designed to do just that. So the parenthetical use of ' $p$, I believe' will always be available to express mere belief, though often enough, 
the non-parenthetic form used in (1) will serve to do this as well. ${ }^{1}$

But Slote did not go on to point out the striking fact that although we can use 'I know' in the prefaced construction akin to (1), it does not naturally take on a parenthetical position:

(4) I know it is raining.

(5) ? It is, I know, raining.

(6) ? It is raining, I know.

KAA is in a good position to explain why. If parenthetical uses serve to express a mental state, then the fact that we don't, or can't, use a parenthetic construction with 'know' as in (5) or (6) must be because, as KAA maintains, the flat-out assertion already serves to express one's knowledge. English doesn't need parenthetical uses of the form exhibited by 'It is, I know, raining' or 'It is raining, I know' because the flat-out 'It is raining' already serves to express one's knowledge that it is raining. ${ }^{2}$

${ }^{1}$ 2010: 97. Slote goes on (p. 98) to claim that 'I think...', which also takes on these parenthetical positions, could also serve a similar role, but that in his view 'think' is generally weaker than 'believe,' in that it often doesn't express the 'full measure of belief.' This seems right at least in that we can use tonal emphasis to stress the weaker notion, as in 'I think there's a bathroom in that building' - such intonation serves to signal something as weak as a mere inkling or hazy recollection, and so nothing as full bodied as belief.

${ }^{2}$ Someone may in fact hear (5) or (6) as natural, along the lines of

(5a) It is, I now know, raining.

(6a) It is raining, I now know.

(5b) It is, as we all know, raining.

(6b) It is raining, as we all know.

(5c) It is, to my knowledge, raining.

(6c) It is raining, to my knowledge.

What I think this shows is that the original (5) and (6) really are unnatural enough that they must be reinterpreted. In (5) and (6) 'know' is an expressively redundant parenthetical adjunct but in the (a) and (b) variants is made non-redundant by conveying something else beyond (one's knowledge of) the proposition it parenthetically modifies: for (5a) and (6a) the point is to convey a contrast with an earlier time at which it wasn't known; for $(5 \mathrm{~b})$ and (6b), it's to convey that a salient group knows. Contrast the (c) examples, which sound somewhat hedged, more akin to 'It is, as far as I know, raining,' which isn't a flat-out assertion that it's raining: indeed, the latter seems much like 'It might be raining,' or 'I don't know it's 


\section{Unifying data}

It has gone unnoticed how the data from Moore's problem sentences relate to some of the conversational data, particularly the challenge questions 'How do you know?' and 'Do you know that?'3 Unger (1975: ch. 6, §§3 and 4 ), and Williamson following him, separated the data into these two camps, and thus the evidence from each has been presented in independent fashion. But in fact, the evidence from the Moorean paradoxical construction

(7) \# It is snowing and I don't know that it is

and the evidence from challenge questions are related in a way that only KAA is well positioned to explain. For the 'How do you know?' challenge can elicit a de facto Moorean paradox within a conversational context:

A: It is snowing.

B: How do you know?

A: Oh, I don't.

B: Huh??

A: Still, it's snowing. ${ }^{4}$

B's question effectively puts A into a potential Moorean predicament. ${ }^{5}$ The not raining'.

So these alternatives aren't all that similar to $(5)$ and (6), which are supposed to be sentences in which one uses parenthetical position simply to express one's knowledge of the proposition (and nothing else). Thanks to John Turri here.

${ }^{3}$ Although a passage in Moore (1993: 211) implicitly connects them, since he mentions the 'How do you know?' challenge on the heels of discussing the belief-version of the paradox.

${ }^{4}$ Maitra and Weatherson (2010: 110-11) appeal to a conversation wherein such responses are (they think) non-defective. Though I find their case unconvincing, it nevertheless does not cast doubt on my point here, for it is not used to argue that no challenge questions in conversation could put one in a Moorean predicament.

${ }^{5}$ Williamson notes in passing that the arguments from Moorean constructions 'apply only to utterances of the conjunction within a single context', since the standards for knowledge might well become elevated between utterances (2000: 254); yet the above dialogue doesn't seem like it elevates any epistemic standards (and if, to your ears, it does, try to hear B's question as being merely a question, rather than a challenge). Keeping the epistemic standards fixed across the conversation, it still sounds bad for A to respond as she does. 
lesson is that any explanation of what is problematic about the Moorean conjunction ought also to explain why the challenge questions are so apt, and vice versa: and even better, they ought to be given the same explanation. KAA does just that: because assertions represent their speakers as knowing, A's assertion invites the supposition that A knows; likewise, because assertions represent their speakers as knowing, any flat-out asserted conjunct of a Moorean sentence invites the supposition that its asserter knows it. ${ }^{6}$

There is a very general schema for explaining the Moorean conjunctions, one which any normative account of assertion can deploy: it's impossible to assert properly ' $p$ and I don't $X$ that $p$ ' if

(a) The norm of assertion is $Y$; and

(b) It is impossible to $Y^{7}$ that: $p$ and I don't $X$ that $p$.

I argue that only by substituting 'know' for $X$ and 'knowledge/know' for $Y$ will one be in a good position to explain the aptness of the challenge questions, because only by doing so will one be able to explain both them and the Moorean paradoxes by appeal to the same notions.

In sum: opponents of KAA have wrongly assumed that rival accounts need only show that they too can handle the data supporting the knowledge account. In fact, the burden is to show that they can handle it as well, or even better than, KAA. One way of doing this is to give an elegant and unified explanation of some of the data; but at least with respect to challenge questions and Moorean paradoxes, this standard has not yet been met. ${ }^{8}$

\section{Rutgers University \\ 1 Seminary Place \\ New Brunswick, NJ o8go1 \\ mbenton@philosophy.rutgers.edu}

\footnotetext{
${ }^{6}$ This is significant because KAA's competitors fare poorly at providing a unified account of the challenge questions and the Moorean conjunctions; indeed, they handle the data in a fragmented way, citing distinct considerations for each. For example Weiner 2005, Douven 2006, and Kvanvig 2009.

7 Or ' $Y$-fully assert (with a point)', if the favoured account is the Truth norm.

${ }^{8}$ Many thanks to Ernest Sosa, John Turri, and Brian Weatherson for helpful feedback.
} 


\section{References}

Douven, Igor. 2006. "Assertion, Knowledge, and Rational Credibility." The Philosophical Review 115: 449-485.

Kvanvig, Jonathan L. 2009. "Assertion, Knowledge, and Lotteries.” In Patrick Greenough and Duncan Pritchard (eds.), Williamson on Knowledge, 140-160. Oxford: Oxford University Press.

Maitra, Ishani and Weatherson, Brian. 2010. "Assertion, Knowledge, and Action." Philosophical Studies 149: 99-118.

Moore, G.E. 1993. "Moore's Paradox.” In Thomas Baldwin (ed.), G.E. Moore: Selected Writings, 207-212. London: Routledge.

Slote, Michael. 1979. "Assertion and Belief." In Jonathan Dancy (ed.), Papers on Language and Logic, 177-191. Keele: Keele University Library. Reprinted in Slote (2010): 94-102.

- 2010. Selected Essays. New York: Oxford University Press.

Turri, John. 2010. "Epistemic Invariantism and Speech Act Contextualism." The Philosophical Review 119: 77-95.

- 2011. "The Express Knowledge Account of Assertion." Australasian Journal of Philosophy 89: 37-45.

Unger, Peter. 1975. Ignorance: A Defense of Skepticism. Oxford: Clarendon Press.

Weiner, Matthew. 2005. "Must We Know What We Say?" The Philosophical Review 114: 227-251.

Williamson, Timothy. 2000. Knowledge and its Limits. Oxford: Oxford University Press. 